\title{
LEGISLATIVE INTENT: THE USE OF POSITIVE POLITICAL THEORY IN STATUTORY INTERPRETATION
}

\author{
MCNOLLGAST*
}

\section{INTRODUCTION}

Recent legal research on statutory interpretation has raised questions about the usefulness of legislative history-committee reports, hearings, floor debates-in assisting judges in interpreting the intent of legislation. Many legal scholars have expressed skepticism on the grounds that majority rule decisionmaking is chaotic (the Arrow Impossibility Theorem) and that members of the legislature may shirk their responsibilities or engage in strategic misrepresentation of their preferences and expectations. This article applies the economics of information and organization to examine the structure of the legislative process in order to identify how legislators solve the problem of instability of majority rule and to identify the activities in which members have an incentive to reveal truthfully their agreements about the intended effects of a statute, as contrasted to activities in which lawmakers may engage in "cheap talk" without fear of negative consequences. From this analysis, we identify aspects of the legislative history that are more reliably informative about the intent of the majority coalition that enacted a statute. We then apply these results to evaluate the judicial interpretations of two important environmental statutes, the Clean Air Act of 1970 and the National Environmental Policy Act of 1969. We find that the interpretation of the former act relied primarily on cheap talk, while the interpretation of the latter act relied on more trustworthy, consequential actions by pivotal members of the enacting coalition.

During the 1980s, legal scholarship on principles for interpreting statutes experienced a renaissance, producing a prodigious and far-ranging literature. For the most part, this work is oriented toward identifying interpretive principles that, in some sense, produce "good" public policy or that are otherwise normatively compelling. The motivation for this work was the development of influential new theories in other disciplines that challenged the intellectual foundations of previous ideas about statutory interpretation. One such

\footnotetext{
Copyright $\odot 1994$ by Law and Contemporary Problems

* Professor of Political Science at the University of California, San Diego; Morris M. Doyle Professor of Public Policy at Stanford University; and Senior Fellow at the Hoover Institution and Professor of Political Science at Stanford University. Especially useful comments on an earlier version of this article were provided by Robert Bates, William Eskridge, Roberta Romano, Kenneth Shepsle, and Thomas Schwartz. The research assistance provided by Jonathan Katz, Brian Sala, and Michael Thies is gratefully acknowledged. The research reported here was supported in part by the John and Mary Markle Foundation.
} 
development was the post-structuralist revolution in literary criticism, based upon twentieth-century developments in the philosophy of language. The new critical theory challenged the notion that in any meaningful sense a reader can uncover the intention of an author. The other development was the appearance of modern positive theories of politics. These models focused on two rather pessimistic views of policymaking: that government was controlled by organized special interests who capture the coercive power of government to feather their own nests, and that democracy was fundamentally unpredictable and chaotic. Both views challenged the normative significance of the policies emanating from democratic political processes.

In our view, the recent literature on interpretation can usefully be separated into three categories. ${ }^{1}$ The first, associated with critical legal theorists, ${ }^{2}$ amounts to a counsel of despair. As with the Queen of Hearts, words mean precisely what the person in authority says they mean, without constraints derived from interpretive principles. The second, sometimes referred to as the "new textualism," is associated with the strict textualists ${ }^{3}$ but has its roots in the nineteenth-century presumption that common law and private arrangements have greater claims to legitimacy than statutory law. This view calls for narrow and limited readings of statutes. The essential message is that when statutory language is unclear, conflicting, or incomplete, the statute does not apply.

The third category, comprising the most recent articles on interpretation, seeks to develop interpretive principles that avoid the pitfalls identified by critical and positive political theories. ${ }^{4}$ In general, this work assumes that the pathologies of politics and the indeterminacy of language are important, but not so pervasive that they require abandonment of the interpretive project. In simplified, stylized terms, when someone is faced with applying a statute, this literature recommends an interpretive agenda of roughly the following form: ${ }^{5}$

1. This categorization of the literature was suggested to us by William Eskridge.

2. See, e.g., Stanley E. Fish, Is There a Text in This Class? The authority of INTERPRETIVE COMMUNITIES (1980); ROBERTO M. UNGER, KNOWLEDGE AND POLITICS (1975).

3. See, e.g., Frank Easterbrook, Statutes Domains, 50 U. CHI. L. REV. 533 (1983)

4. Recent articles in this category include William N. Eskridge, Jr. \& Philip P. Frickey, Statutory Interpretation as Practical Reasoning, 42 STAN. L. REV. 321 (1990); Cass R. Sunstein, Interpreting Statutes in the Regulatory State, 103 HARV. L. REV. 407 (1989).

Eskridge further divides this group into "original intentionalists," such as RICHARD A. POSNER, THE FEDERAL COURTS: CRISIS AND REFORM (1985); Earl M. Maltz, Statutory Interpretation and Legislative Power: The Case for a Modified Intentionalist Approach, 63 TUL. L. REV. 1 (1988); Thomas W. Merrill, The Common Law Powers of the Federal Courts, 52 U. CHI. L. REv. 1 (1985); and "dynamicists," including GUIDO CALABRESI, A COMMON LAW FOR THE AGE OF STATUTES (1982); Eskridge \& Frickey, supra; T. Alexander Aleinikoff, Updating Statutory Interpretation, 87 MICH. L. REV. 220 (1988).

5. As a practical matter, these steps do not form a temporal sequence, but instead a logical one. As Posner has observed, the natural starting place for a judge who seeks to interpret a statute is usually previous judicial interpretations, typically as cited in the briefs submitted by the parties to a case. See Richard A. Posner, Statutory Interpretation-in the Classroom and in the Courtroom, 50 U. CHI. L. REV. 800,808 (1983). We are interested in the logical sequence of the first judicial interpretation of new statutory language. 
1. Read the text; if it is not clear, then proceed to step two.

2. Consider the overall structure and purpose of the statute as written and, where relevant, other related statutes; if it is still not clear, then proceed to step three.

3. Consult the legislative history to see if, in the course of the legislative process, elected political officials left a record about how ambiguities should be resolved, and proceed to step four.

4. Based on the information collected in the previous steps, ascertain whether the statutory provision in question reflects politically legitimate values or the pathologies of representative democracy; if the statute remains ambiguous, or if it reflects a democratic pathology, then proceed to step five.

5. Invoke normative principles (varying among the authors) to determine whether the statute should be applied, and if so, how to resolve the ambiguities and compensate for the pathologies.

Of course, scholars differ in the extent to which they believe that intentionalism, even through "imaginative reconstruction," can solve interpretive problems. Nevertheless, all work in the third category includes some role for going beyond the specific passage of the text to ascertain its purpose as understood by those who created it. However, the legal literature to date lacks an approach to the broader methods of statutory interpretation that is fully compatible with how legislation is actually created and how elected officials oversee the implementation of policy by agencies and courts. As Richard A. Posner has observed, methods of statutory interpretation "are not guided by an overall theory of legislation, and most academic lawyers, like most judges and practicing lawyers, would consider it otiose, impractical and pretentious to try to develop one."7

In this article, we propose a method for interpreting legislation that is grounded in a positive theory of the behavior of legislators and the president. ${ }^{8}$ This method can help judges and other interested observers make use of the varied and often contradictory statements and actions of legislators and the president during the legislative process to infer the policy agreement that is embodied in a statute.

Our interpretive method overlaps the legal scholarship that instructs the court to ascertain as accurately as possible the "original intent" of legislation, by which is meant the actual agreement about policy among those enacting a statute. ${ }^{9}$ Our

6. POSNER, supra note 4 , at 287.

7. Posner, supra note 5 , at 800 .

8. For a discussion of positive political theory, see Daniel A. Farber \& Philip P. Frickey, Foreward: Positive Political Theory in the Nineties, 80 GEO. L.J. 457 (1992).

9. For examples of this standard approach to statutory interpretation, see William N. Eskridge, Jr., Politics Without Romance: Implications of Public Choice Theory for Statutory Interpretation, 74 VA. L. REV. 275 (1988); Daniel A. Farber, Statutory Interpretation, Legislative Inaction, and Civil Rights, 87 MICH. L. REV. 1 (1988); Jonathan R. Macey, Promoting Public-Regarding Legislation through Statutory Interpretation: An Interest Group Model, 86 CoLUM. L. REV. 223 (1986); Daniel B. Rodriguez, Statutory Interpretation and Political Advantage, 12 INT'L REV. L. \& ECON. 217 (1992). Of course, not only judges will be interested in interpretive principles of this form. If judges attempt to interpret statutes according 
approach differs from this literature in that our focus on original intent need not be based on a normative theory of how courts ought to behave. ${ }^{10}$ If a judge or bureaucrat believes that the argument for implementing policy in the manner intended by those who created a statute is normatively compelling in at least some cases, then an interpretive method that uncovers this intention is useful. But regardless of the motives of those who implement and enforce policy, bureaucrats, judges, and citizens who are directly affected by a statute need to have a reasonably accurate method of ascertaining the policy intent of a statute in order to respond rationally to it, even if this response is something other than faithful fealty to that original intent. ${ }^{11}$ If judges, bureaucrats, and lawmakers all seek to pursue their own antagonistic policy objectives, each group needs to take the others into account to accomplish its purposes.

For example, a court must obtain bureaucratic compliance with its interpretations of the law if its policy directives are to be implemented, and it must obtain legislative compliance if the bureaucracy is to retain its policy mandate and is to be given sufficient resources to carry out the court's wishes. ${ }^{12}$ Moreover, the authority of a court to interpret statutory intent and enforce the law depends upon powers and resources given to it by statute. Thus, in pursuing its own policy objectives, a court is constrained to act within limits that are acceptable to other political actors. Consequently, to shape policy as closely as possible to its own preferences, a court must take into account the nature of the agreement that lawmakers thought that they were making (and thought the agencies and courts would implement) when enacting legislation. Hence, the normative issue concerning how statutes ought to be interpreted, assuming that their objective is to spell out faithfully a legislative bargain, closely parallels the positive theory of the adoption of interpretive canons.

In a previous article ${ }^{13}$ we argued that the positive political theory of statutory enactment provides significant insights about the meaning of a legislative bargain among members of the coalition enacting a statute. That article focused on using

to the original intentions of lawmakers, agencies and citizens must engage in a similar exercise if their actions are to be upheld when challenged in the courts. For scholars and judges who advocate deference to agencies in interpreting statutes, the interpretive canons in the legal literature can be reread as normatively compelling recommendations to agencies. And, for scholars who propose that judges first ascertain whether a statute serves general or special interests, and then apply broad interpretive canons to the former but narrow readings to the latter, the problem of ascertaining legislative intent initially takes a somewhat different, but conceptually similar approach: Positive theory can be used to determine whether a statute is intended to serve a narrow, private interest in the same way that it can be used to infer the nature of the policy agreement.

10. See John Ferejohn \& Barry Weingast, Limitation of Statutes: Strategic Statutory Interpretation, 80 GEO. L.J. 565 (1992); McNollgast, The Theory of Interpretive Canon and Legislative Behavior, 12 INT'L REV. L. \& ECON. 235-38 (1992); Rodriguez, supra note 9.

11. See William N. Eskridge, Jr. \& John Ferejohn, The Article I, Section 7 Game, 80 GEO. L.J. 523 (1992); Jonathan R. Macey, Separated Powers and Positive Political Theory: The Tug of War Over Administrative Agencies, 80 GEO. L.J. 671 (1992); Rodriguez, supra note 9.

12. On this line of reasoning, see MARTIN SHAPIRO, WHO GUARDS THE GUARDIANS: JUDICIAL CONTROL OF ADMINISTRATION (1988).

13. McNollgast, Positive Canons: The Role of Legislative Bargains in Statutory Interpretation, 80 GEO. L.J. 705 (1992). 
positive theory to identify the members of an enacting legislative coalition and, in particular, the political actors who were pivotal in that their preferences had to be taken into account in order for a legislative agreement to be made. In this article, we extend our argument by incorporating the principles of the economics of information-in particular, signaling behavior by political actors. We develop principles for identifying the actions and statements by a legislator and the president that convey meaningful signals about actual preferences.

As extended, our approach to ascertaining statutory intent deals with two issues: first, identifying the pivotal political actors who formed a majority coalition in enacting a bill, and second, detecting the actions that reveal their policy preferences. Both are essential to discovering the nature of the agreement that the members of the coalition thought they were making. In particular, ascertaining legislative intent requires separating the meaningless actions (or signals) of participants in the legislative process from the consequential signals that are likely to reveal information about the coalition's intentions.

We use the term "pivotal" in a broader sense than simply the "swing" voters in Congress who must be induced to vote for a bill if it is to be enacted. As we use the term, anyone who occupies a "veto gate" in the institutional structure of legislative decisionmaking is also pivotal. Think of the legislative process as a decision tree, in which different members of the legislature are assigned different responsibilities at various decision nodes. A pivotal member is one whose action at a particular node can determine which branch of the tree the process will subsequently follow. For example, the rules of Congress permit the chair of a subcommittee that has jurisdiction over a legislative proposal unilaterally to decide not to allow it to be considered, or to insist that it contain certain provisions if it is to be reported out of committee. Such actions may or may not change the ultimate outcome of the legislative process, for decisions of committee chairs can be overturned. In general, the actions of pivotal members at early or intermediate stages of the process can always be overturned by subsequent actions; however, overturning the decision of a pivotal actor is costly. The ability to impose costs on subsequent decisionmakers who wish to reverse a previous decision gives early-stage pivotal actors influence over the final legislative outcome. The greater the costs that subsequent players must bear to overcome an earlier action, the more influential the player who takes that action will be. ${ }^{14}$

Signaling is, of course, a major preoccupation of politicians. They frequently make speeches, issue press releases, publish policy reports and studies, grant interviews, write constituents, and propose bills. Those who are legislators also

14. In the positive theory of majority-rule voting, pivotal players arise from the distribution of preferences. For example, if the policy space is confined to a single dimension and the agenda is limited to binary choices, the member whose preferences are at the median of the distribution will be pivotal in that all winning coalitions must contain this member. Of course, a political actor who occupies a veto gate is pivotal in this sense, albeit in a trivial way, in that a veto player can be regarded as the median voter in a single-member constituency. 
cast votes and make procedural motions during the consideration of a bill. Probably the most persuasive argument against using the legislative history in statutory interpretation is that politicians sometimes misrepresent their actual policy preferences. Hence, a theory of statutory interpretation that makes use of legislative history bears the burden of proving that some signals are reasonably reliable indicators of what lawmakers thought they were doing when enacting legislation. To discover the nature of the agreement that emerges from a legislative process, one must develop criteria for determining which of these signals are meaningful.

In general, an observer (a jurist) who is uninformed (for example, about legislative intent) can learn from a signal of an informed party (a legislator) in either of two circumstances. First, the observer can learn whether the informed party bore some cost to communicate the signal. Although the content of the signal may be meaningless to the observer, the fact that the informed party bore a cost to communicate it nonetheless tells the observer that the informed party believed that the benefit of communicating would likely outweigh the cost incurred to do so. Second, if the informed party can be punished for sending false signals, the observer can conclude that some lies are unprofitable for the informed party (those for which the expected benefit for lying is less than the expected penalty). This reasoning allows the observer to conclude that certain signals are more likely to reffect the truth than are others.

We use the general principles of signaling behavior to identify the actions and statements in a legislative history that can provide an outside observer with information about the interests and expectations of the parties to an agreement and, thereby, about the intent of a statute. Actions taken at key nodes in the congressional process-for example, votes by members of a committee to recommend a bill to the floor-are costly in terms of effort and foregone opportunities. In other cases, such as majority reports of committees, false or misleading signals subject their makers to penalties.

In the remainder of this article we present in detail the argument sketched above and apply our method of statutory interpretation to two important cases. In part II we argue that relevant officials-lawmakers, bureaucrats, and judges-have an interest in developing a mutually accepted system of interpreting statutes that reveals, as closely as possible, the intent of the coalition within the House and Senate (most often together with the president) that enacted the statute. Part III uses the contemporary theory of legislative decisions, based on the effects of the structure and process of the development of legislation, to identify the pivotal actors in creating statutes and to provide an explanation for why the concept of statutory intent by the enacting coalition is meaningful, despite the well-known pathologies of majority-rule representative democracy. Part IV makes use of the economics of information to develop a model of learning from signals in the legislative process. Part $\mathrm{V}$ applies the model of statutory interpretation developed in the previous two sections to a well-known, controversial case: Judge Skelly Wright's 1971 circuit court decision in Calvert 
Cliffs Coordinating Committee v. United States Atomic Energy Commission. ${ }^{15}$ This decision clarified the applicability of the National Environmental Policy Act of 1969 ("NEPA") to the Atomic Energy Commission ("AEC"). We compare this decision to the outcome of Sierra Club v. Ruckleshaus in 1972, which we have analyzed elsewhere, ${ }^{16}$ wherein Judge John H. Pratt ruled that the Clean Air Act of 1970 required that the Environmental Protection Agency adopt the "Prevention of Significant Deterioration" policy in areas with pristine air quality. ${ }^{17}$ Both decisions came down firmly in favor of interpretations favored by environmentalists; however, our reading of the two decisions shows that only the Calvert Cliffs decision was based on a clearly valid reading of the legislative history. Part VI contains our conclusions.

\section{II}

\section{PURPOSES OF STATUTORY INTERPRETATION}

The fundamental assumption of our approach, not uncommon in the literature, is that legislation shares many characteristics with contracts. ${ }^{18}$ Both formalize bargains among actors with diverse and partially conflicting interests. Because agreements that provide for every contingency are costly, if not impossible, to negotiate, contracts typically do not cover every potentially relevant issue and so leave unresolved gaps. As A. Mitchell Polinsky writes,

[c]ontract law can be viewed as filling in these "gaps" in the contract-attempting to reproduce what the parties would have agreed to if they could have costlessly planned for the event initially. Since the parties would have included contract terms that maximize their joint benefits net of their joint costs-both parties can thereby be made better off . . . . ${ }^{19}$

If the analogy between legislation and contracts is extended to matters of legal interpretation, the role of the courts is to fill in the gaps in legislation by interpreting the intentions of the law's enacting coalition. To determine legislative intent, courts have relied on a wide range of evidence about the parties involved, including information about their preferences, intentions, and expectations at the time of the agreement and data about the relevant constituencies affected by the legislation.

Of particular importance to the courts has been the paper trail of commentary and debate in the legislative record or legislative history. Within the legislative record, however, judges and scholars have often found widely

15. 449 F.2d 1109 (D.C. Cir. 1971).

16. Mathew D. McCubbins et al., Structure and Process, Politics and Policy: Administrative Arrangements and the Political Control of Agencies, 75 VA. L. REV. 431 (1989).

17. 334 F. Supp. 253 (D.D.C. 1972).

18. See Daniel A. Farber, Legislative Deals and Statutory Bequests, 75 MINN. L. REV. 667 (1991); Gillian Hadfield, Incomplete Contracts and Statutes, 12 INT'L REV. L. \& ECON. 257 (1992).

19. A. MITCHEll POlinsKy, AN INTRODUCTION TO LAW AND ECONOMICS 27 (1989); see also ROBERT COOTER \& THOMAS ULEN, LAW AND ECONOMICS (1988). 
divergent interpretations of the same provision of a law. One key challenge for an interpretive method is determining how to ascertain which of these indicators actually reveals the bargain reached by the enacting coalition.

A second problem of statutory interpretation is how to apply legislation when circumstances arise that were not explicitly taken into account in the legislation. Scholars of statutory interpretation have long recognized that ambiguity about future contingencies is a problem for all legislation. ${ }^{20}$ Again, applying the contract analogy, an interpretive system that is based on the original agreement of the parties would seek to ascertain whether the parties would have wanted the new circumstance to be covered by their bargain, and if so, how the policy should be extended to accommodate it.

We approach these interpretive problems by examining the events in the legislative history in which the bargains among pivotal lawmakers are made. The Constitution and the standing rules of the House and Senate define the decisionmaking stages in the legislative process. Positive political theory identifies which actions by which actors both influence and reveal the bargains that are being struck.

\section{A. Positive Political Theory and Legislative Intent}

Positive political theory ("PPT") has been concerned with two central issues: collective action and delegation. The collective action problem concerns how governing institutions, populated by representatives elected under differing electoral structures and holding differing policy objectives, make durable bargains about public policy. ${ }^{21}$ A continuing theme of much of the theoretical literature on collective action has been the instability of collective choice in majority-rule institutions such as legislatures. Reaching a legislative agreement is made all the more difficult in politics in the U.S. by a constitutional structure that requires enacting coalitions to encompass majorities in both houses of Congress and to gain the support of the White House. Moreover, the durability of agreements, once made, is uncertain because the entire coalition that enacts a statute is unlikely to remain in office for more than a few months after the statute is passed.

The delegation problem concerns how elected officials can grant authority to others to develop and implement policy without losing influence over its content. $^{22}$ Because the development of new policy requires time and expertise,

20. See, e.g., Posner, supra note 5, at 806-07.

21. See, e.g., William M. RIKER, Liberalism Against Populism: A CONFRONTATION BETWEen THE THEORY OF DEMOCRACY AND THE THEORY OF SOCIAL CHOICE (1982).

22. Mathew D. McCubbins et al., Administrative Procedures as Instruments of Political Control, 3 J.L. ECON. \& ORG. 243, $243-78$ (1987); Gary Miller \& Terry Moe, The Positive Theory of Hierarchies, in Political SCIENCE: The SCIEnCE OF Politics (Herbert Weisberg ed., 1986); ; Terry M. Moe, The Politics of Bureaucratic Structure, in CAN THE GoverNMENT GOVERN? (John E. Chubb \& Paul E. Peterson eds., 1989); Pablo Spiller, Politicians, Interest Groups, and Regulators: A Multiple-Principals Agency Theory of Regulation (or "Let Them Be Bribed"), 33 J.L. \& ECON. 65 (1990); Kathleen Bawn, 
Congress delegates this responsibility to committees in the House and Senate, and also to their staff ${ }^{23}$ or to the executive branch. Individual legislators tend to specialize in a few policy areas, relying on other specialists to develop other policies. Once a legislative bargain has been struck, legislators must delegate the authority to implement policies to executive branch officials. The problem legislators face is how to delegate authority without losing control of policy.

Legislation plays an important role in solving both problems. With respect to the collective action problem, statutes define and record the details of the bargain reached among majorities in the House and Senate, as well as, most often, the president. In this sense, legislation is the embodiment of collective action. Moreover, the rules and structure of the legislative process lend durability to an otherwise unstable collective action, because they endow authority to specific legislators whose interests (presumably) are well-known and stable. The legislature can choose a degree of difficulty for changing a policy bargain through its choice of institutional rules and structures. For example, attempts to pass new legislation typically must navigate through numerous veto gates before even reaching the presidential approval/veto stage: agreement must be reached among House and Senate committees, the majority party leadership in both chambers, majorities in both chambers, and the president. ${ }^{24}$ Consequently, it is difficult and time-consuming to change most prior legislative bargains.

Political Control vs. Expertise: Explaining Differences in Administrative Arrangements (1991) (unpublished manuscript, on file with UCLA Department of Political Science); Pablo Spiller \& Santiago Urbiztando, Interest Groups and Control of the Bureaucracy (1991) (unpublished manuscript, on file with University of Illinois Department of Economics).

23. Legal scholars have questioned the idea that statutes and committee reports represent an agreement among lawmakers on the grounds that both are written in significant measure by staff or even lobbyists and that, in any case, only committee members are likely to pay much attention to the drafting of either. For example, then-Judge Scalia, based on the observation that most legislators do not read committee reports, concluded that "routine deference to the detail of committee reports [is] ... converting a system of judicial construction into a system of committee-staff prescription." Hirschey v. F.E.R.C. 777 F.2d 1, 8 (D.C. Cir. 1985) (concurring opinion). Easterbrook's argument for strict textualism and narrow construction is based in part on these observations. Easterbrook, supra note 3. But this view is simply one version of the more general delegation problem, and it does not take into account the lessons of principal-agent theory. The observation that committees and their staffs do most of the legislative work and that the floor majority rarely inspects all of their efforts implies nothing about whether the floor majority has abdicated its formal role. If the floor has created effective incentives for its committees and staff in its structure and process, it need not constantly monitor their work product to assure compliance with the interests of the floor majority. Again, the contracting analogy is useful. One cannot argue that a contract between two parties does not embody their mutual agreement because both parties delegated the negotiation to their lawyers and then signed it after only superficial perusal of its contents. Presumably clients delegate the job of negotiating contracts to their lawyers because they can rely on the incentive structure of the attorney-client relationship. This reliance enables them to obtain the expertise of a lawyer without fearing that their interests will be ignored in drafting an agreement. The same logic applies to decisions by a legislature on its structure and process.

24. Thomas H. Hammond \& Gary J. Miller, The Core of the Constitution, 81 AM. POL. SCI. Rev. 1155 (1987); Kenneth Shepsle, Institutional Arrangements and Equilibrium in Multidimensional Voting Models, 23 AM. J. POL. SCI. 27 (1979); Kenneth Shepsle \& Barry Weingast, Structure-Induced Equilibrium and Legislative Choice, 37 PUB. CHOICE 503 (1981). 
With respect to the delegation problem, statutes are also instructions to bureaucrats concerning policy. The language of a statute can be regarded as a statement of the preferences of a fictitious decisionmaker who embodies the compromises that solved the collective action problem. If the coalition has agreed to a system of rewards and punishments to induce the bureaucracy to carry out its legislative agreement, the statute constitutes a statement to the bureaucracy of the criteria that will be used to implement these incentives. Statutes also contain agreements about organizational structure and decisionmaking procedures for the implementing bureaucracy. ${ }^{25}$ Structure and process affect agency decisions by controlling the actions that the agency may consider, the information that the agency may use to make decisions, the extent to which the agency must announce its intentions (and hence warn of potential noncompliance with the coalitional agreement embodied in the statute), and the extent to which agency decisions are subject to appeal. ${ }^{26}$ Thus, the structure and process of an agency are determined through a legislative bargain about the interests that the agency is supposed to serve, and consequently are a part of the policy agreement. ${ }^{27}$ These rules and procedures tend to have a stabilizing effect on policy implementation for two reasons. First, much of the bureaucracy is composed of career civil servants. Legislators thus can collect a wealth of information about the behavior of these bureaucrats under different circumstances, and thereby make credible inferences about their private motivations and interests, which they can then incorporate into the rules and procedures they use to shape the implementation of a new policy. Second, by varying the incentives offered to bureaucrats, legislators can also induce some individual types to select out of and others to select into bureaucratic careers. Hence, legislative design may actually contribute to the stocking of the executive branch career service with "Burkean" public servants.

\section{B. The Stake of Lawmakers in Interpretive Method}

For statutes to serve their function as instructions to agencies and courts, legislation must be regarded by relevant political actors as a reasonably reliable determinant of policy outcomes. In the first instance, the members of the enacting coalition must have confidence that, although they have different policy preferences, the statute constitutes a mutual agreement over policy that improves upon existing policy. Otherwise, statutes cannot reliably serve the purpose of embodying their solution to the collective action problem. Bureaucrats must also have confidence that they can understand the statute. Otherwise, they cannot

25. McCubbins et al., supra note 16 .

26. SHAPIRO, supra note 12; see also ARTHUR BONFIELD \& MICHAEL ASIMOW, STATE AND Federal Administrative LAW (1989); Richard B. Stewart, The Reformation of American Administrative Law, 88 HARV. L. REV. 1669 (1975).

27. McCubbins et al., supra note 16. 
respond rationally to rewards and punishments that the enacting coalition has adopted to induce compliance with its agreement. ${ }^{28}$

Reliability in interpreting the meaning of a statute is inherently difficult to assure. Unfortunately, only rarely can statutory language be precise in conveying either policy bargains or instructions to agencies. Nature has a nasty habit of creating situations in which the applicability of a statute is unclear. But even if nature were not unkind, the meaning of statutes would still be problematic because language is inherently imprecise and because rational political actors, having numerous competing ways to occupy their time, would never devote the effort necessary to minimize the indeterminacy of statutory language. Consequently, a set of coherent, commonly understood principles for ascertaining the intended meaning of unclear statutory provisions is valuable to legislators because it reduces the uncertainty surrounding the policy consequences of a statute and, thereby, increases the ability of legislators to achieve their policy objectives.

In writing a statute, those who have been given the job of striking a bargain among the coalition members can be regarded as facing a form of constrained optimization problem. The enacting coalition and the staff who work for its members allocate a valuable resource-their time and effort-to activities leading to a new statutory policy. One such activity is negotiating what the policy will be, which requires compromising their differences. Another is writing statutory language for each provision in the statute, including the provisions governing the structure and process of the implementing bureaucracy and the nature of judicial review of the agency's decisions. Still another action available to them is to agree to language that will instruct agencies and courts on how to interpret ambiguous or contradictory provisions in the statute. ${ }^{29}$ Finally, given the principles of interpretation that the coalition adopts or that its members anticipate the courts will use, members of the coalition can undertake strategic activities to influence the interpretation that agencies and courts in fact adopt, such as issuing reports and making statements on the floor to elaborate the meaning of a bill..$^{30}$

28. This argument is not inconsistent with the view that in some cases a legislative coalition will not resolve its policy differences, but instead will enact a "policy lottery" through a vague statute, thereby "shifting the blame" for a potentially controversial outcome on the implementing agency or the courts. See, e.g., Morris P. Fiorina, Group Concentration and Delegation of Legislative Authority, in REGULATORY POLICY AND THE SOCIAL SCIENCES (Roger G. Noll ed., 1985). In this case, the legislative history is properly interpreted as, first, delegating broad authority, but second, either by direct statement or inferentially through the choice of structure and process, setting boundaries on the acceptable policy outcomes. At this point, judges and legal scholars can debate whether the court should declare the statute invalid, should defer to the agency's decision about where within the boundaries to select a policy, or should make use of some normative principles to narrow still further the range of acceptable agency decisions. Our interpretive program is useful in all of these cases, because it enables outside observers to determine whether the statute is vague, whether its vagueness is intentional, and what boundaries on policymaking by an agency it contains.

29. For examples, see Rodriguez, supra note 9.

30. We do not mean to imply that strategic behavior necessarily involves legislators misrepresenting their preferences over policy outcomes. By strategic behavior we merely mean that legislators attempt 
The solution to this optimization problem is unlikely to be either a statute that is worded with perfect clarity or one that is written relatively vaguely but with a crystal clear method of interpretation. Thus, another parallel can be drawn between the legislative process and the negotiation of private contracts. In neither case will the parties to an agreement find it worthwhile to anticipate-and guard against-every conceivable eventuality in reaching a written agreement. Indeed, in both cases the principles of interpretation adopted by the courts will affect the effort devoted to details in the written agreement.

If the parties to an agreement regard the interpretive methods of the court as likely to produce a result that reflects the compromises struck in the original agreement, they need not devote as much effort to fashioning the bargain. Moreover, in areas where the facts are uncertain and knowledge is expanding rapidly, but where legislators know the general direction that they want policy to take, they can fashion imprecise legislation that enables bureaucrats and courts to develop suitable policies as the facts unfurl. Without an interpretive method that is faithful to their intentions, on the other hand, effective legislation would be too risky or perhaps even impossible to craft.

Finally, an interpretive method that is faithful to the legislative agreement means that legislators need not frequently revisit their bargain to redefine it in light of new circumstance. Because legislatures are composed of many members, representing numerous competing interests, rather than the bilateral negotiation reflected in most contracts, frequent renegotiations are likely to be costly and, due to the collective action problem, to have highly uncertain outcomes. Hence, parties to a legislative bargain will place a high value on expansive interpretive principles that reasonably reflect the spirit of the initial agreement. Indeed, the value of expansive readings will be greater for legislation than for contracts.

Interpretive principles, then, are bound to be an integral part of the coalition's agreement about a statute, either explicitly in statutes or implicitly through reliance on continued application of interpretive principles propounded by the courts. Explicit and implicit understandings about interpretive principles are necessary for forming expectations about the effect of statutory language on policy outcomes and the durability of legislative agreements, and for rationally allocating effort in the legislative process. From these insights, one can readily identify several aspects of interpretive methods that members of the enacting coalition will regard as important.

Obviously, legislators will want the foundation of an interpretive principle to be the faithful execution of their agreement. Because no interpretive method is likely to be perfect in reproducing this agreement, and because both legislators and citizens are likely to prefer that policies be stable through time and changed significantly only by new legislation, legislators will also want judicial interpreta-

to forecast how other actors involved in developing a policy will react to alternative institutional structures and take actions that maximize the chance that the new policy will advance their political objectives. For legislators acting as agents for the majority coalition, this objective can be to maximize the probability that the coalition's agreement wilh actually be implemented by agencies and courts. 
tions of statutes to be consistent across cases. If legislators can rely on the stability of the interpretations adopted by the courts, they can anticipate areas where interpretive problems are most likely to arise and focus their efforts for legislative clarification on them. If judicial decisions are inconsistent, their only recourse is greater specificity in both the substance of and statutory guidance about interpretation for all legislation. And, if legislative history contains a cacophony of mutually contradictory indicators of statutory meaning, a set of interpretive principles that does not have a coherent, consistent method for separating the meaningful indicators of intent from inconsequential actions will inevitably lead to inconsistent interpretations.

The conclusion that lawmakers prefer stable, predictable, interpretive principles that are faithful to their agreements does not necessarily mean that agencies and the court will adopt such principles. We will not systematically address this issue here, except to make two observations. First, because stable, predictable, and faithful methods are a necessary component of any interpretive system that is grounded in legislative intent, one who believes that the intended meanings of statutes are normatively compelling policy directives will seek to adopt methods that serve the purposes described here. Second, PPT provides reason to believe that bureaucrats and judges will find value in stable and predictable methods of interpretation that accord significant weight to legislative intent. Although on any given issue decisionmakers may want to ignore statutes and adopt their own preferred policy, they also must recognize that other actors have the power to influence policy and that the process of policymaking is an infinitely repeated game. Hence, if these actors are risk averse they, too, will prefer general decisionmaking principles that avoid chaos and uncertainty, and that reach policy accommodation with other actors, including lawmakers. Whereas the desire for stability and accommodation does not lead to policy implementation that is as faithful as possible to legislative intent, it does lead to policies that take legislative intent seriously into account. ${ }^{31}$

On the basis of the arguments presented in this section, we conclude that legislative intent is an important element of any normatively compelling interpretive method and, more importantly, any interpretive system that realworld lawmakers, judges, and civil servants are likely to adopt. Consequently, developing more reliable methods of ascertaining legislative intent has practical as well as theoretical value. Although the literature on statutory interpretation

31. As an illustration, the recent literature in PPT that deals with policy implementation by agencies and courts defines the domain of bureaucratic and judicial discretion in terms of the policy preferences of the president and the median voter in the legislature. See, e.g., the discussion of irreversible policy deviations in McCubbins et al., supra note 16; the theory of judicial discretion developed in Pablo Spiller \& Rafael Gely, Congressional Control or Judicial Independence: The Determinants of US Supreme Court Labor Decisions, 1949-1987 (1990) (unpublished manuscript on file with the University of Illinois); the view of strategic statutory interpretation put forth in Eskridge \& Ferejohn, supra note 11. Because these policy preferences are not published in the Congressional Record, civil servants or judges who wish to behave in the manner described in these theories need a reliable method of estimating the intent of a statute in order to ascertain the optimal irreversible act of noncompliance with this agreement. 
has identified the problems in reliably uncovering legislative intent and contains many useful insights about how to do so, it has not advanced very far in linking interpretive methodology to the complete extant theory of legislative enactment.

\section{III}

\section{The Theory of Legislative Decisionmaking}

In order to ascertain the intent of a statute, an outsider to the legislative process must be able to determine whose interests were influential in developing the legislative agreement and what bargain was struck. ${ }^{32}$ All bills are bargains among the members of some winning coalition, but the details of a bargain depend critically on the route a bill takes through the decisionmaking structure of Congress. By understanding the legislative path of a bill-including who the decisionmakers were at key stages in the legislative process and what demands they made on the bill-an outside observer can begin to identify the elements of the agreement that the coalition thought it was making that are not explicit in the language of the statute. Because the coalition's agreements represent a compromise among its members, the ascertainment of an implied agreement rests on understanding what interests were compromised.

Two puzzles must be solved in order to create interpretive canons that are consistent with and faithful to legislative bargains. The first is how to identify the members of the enacting coalition, among whom the bargain was struck and whose preferences most affected the dimensions of the bargain. The second is how to identify the preferences of the coalition members.

\section{A. Identifying the Enacting Coalition: Veto Gates and Pivotal Players}

In the United States, more so than in most other democracies, majority rule is tempered by granting minorities both limited veto power over changes in existing policy and, often, control over proposals to change existing policy. The basic structure of government establishes several checks on the ability of legislative majorities to enact their will: Congress is divided into two chambers and acts of Congress must be approved by the president (or failing that, must be

32. Skeptics about the value of making legislation easier for elected politicians do not find this argument for "deep" readings of statutes to be normatively compelling. We do not wish to engage this normative argument here, for our purpose is simply to make two important points: (1) The interpretive canons used by a court will affect the amount and scope of legislation because they affect the effort required for legislating and the certainty of the policy consequences of legislation; and (2) as a matter of positive theory, legislators of the majority party will prefer interpretive methods that attempt faithfully to implement the policy agreement that the enacting coalition thought it was legislating. Because of the second point, attempts by a court to impose interpretive canons that do not serve the purposes of consistency and faithfulness to the policy agreement are likely to cause legislative reactions, in the form of either directions in statutes about how they are to be interpreted or reprisals against the court with respect to its jurisdiction and resources. Hence, as a practical matter the normative argument about the merits of alternative interpretive principles may be unimportant because legislators will take actions to assure that the interpretive principles they prefer are adopted. 
approved by two-thirds majorities in both houses, thus enfranchising certain members excluded from the original congressional majority). The legislative process established by the Constitution has two especially noteworthy characteristics. First, agenda control-control over proposals to change existing policy-is conferred on Congress and is exercised according to the rules and structures that govern congressional decisionmaking. Further, this agenda power is divided between the House and Senate.

Second, unless a veto can be overridden, the president must be a partner in every legislative bargain. This latter point commonly escapes the courts, for virtually all of the evidence cited in court decisions regarding "legislative intent" focuses on congressional activities. ${ }^{33}$ An examination of the president's role in the legislative process leads inexorably to the conclusion that the president is a member of most enacting coalitions. ${ }^{34}$

Unless Congress is sufficiently united to override a presidential veto, the threat of veto constitutes an important check on the content of legislation. The threat of a veto induces members of Congress to take presidential preferences into consideration when writing legislation. For example, a president who prefers lower spending on a program than does the majority party in Congress may be able to force Congress to reduce its spending proposal downwards by threatening to veto higher expenditures. ${ }^{35}$

Two conclusions follow from an analysis of the veto power in situations where a congressional override is impossible: First, we can infer that the president prefers the legislation (and the intentions of the legislation) to the policies that would obtain if the bill were vetoed. Second, we can infer that Congress has accommodated any misgivings of the president about particular portions of the bill by either striking a compromise with the president over those provisions or repackaging the bill so that the president obtains another policy objective elsewhere in the bill in return for accepting some otherwise unpalatable provision.

Congress's legislative record on a policy decision will include the president's views and preferences, sometimes directly, but most often indirectly through the kinds of amendments that are attached to a particular bill or the provisions that are removed prior to final approval in Congress. In either case, the bill contains language somewhere that reflects the president's policy preferences.

Although the threat of veto confers power on the president in shaping legislation, the fact that the president approves a bill at the final stage does little to clarify what the bill means. At this stage, because the statute is presented to the president as a take-it-or-leave-it package, the president's signing of the bill

33. See Rodriguez, supra note 9.

34. For models of the president's veto power, see Eskridge \& Ferejohn, supra note 11; William Eskridge, Reneging on History? Playing the Courts/Congress/President Civil Rights Game, 79 CAL. L. REV. 613 (1991); D. Roderick Kiewiet \& Mathew D. McCubbins, Presidential Influence on Congressional Appropriations, 32 AM. J. POL. SCI. 714 (1988).

35. Kiewiet \& McCubbins, supra note 34. 
only implies that the president prefers the entire package to the policy that would emerge if the bill were vetoed. Because the construction of the legislative package takes place earlier in the process, all presidential actions that could have influenced the content of the legislation have already taken place by the time the bill is signed.

The House and Senate also have vetoes over changes in existing policy. Thus, whoever holds veto positions within the House and Senate can exercise that chamber's veto power. Moreover, whoever controls the agenda for a chamber will exercise that chamber's share of the agenda power. Thus, the rules and structure of the House and Senate are important determinants of how influence over policymaking is shaped and provides the key to understanding who is influential, and for our purposes, whose preferences matter and whose do not.

The single most important feature of the legislative process in the House and Senate is that, to succeed, a bill must survive a gauntlet of veto gates in each chamber, each of which is supervised by members chosen by their peers to exercise gatekeeping authority. ${ }^{36}$ In each chamber of Congress, at least one subcommittee and one full committee have gatekeeping rights in that a bill normally will not be considered by the entire legislative body until it has been approved in committee. In some cases, several committees share responsibility. The majority party leadership must then assent to a bill's consideration on the floor. In the House, floor debate usually takes place under a special rule restricting debate and amendments as proposed by the Rules Committee, which is controlled by the leadership of the majority party. Once the majority party leadership allows the bill to reach the floor, legislation must be approved by majorities in each house. Differences in the bill passed by the two houses must then be resolved, usually by a conference committee composed of supporters of the bill from each chamber. The final product is then sent to the president.

The extent to which a member of an enacting coalition can influence legislation depends on three factors: (1) the member's power to control the agenda of the legislature, such as by holding a gatekeeping position; (2) the amount of information possessed by the member about proposed alternatives and the preferences of others; and (3) the details of the differences in policy objectives among members. Normally, some members of the committees in which legislation originates are pivotal in shaping legislation. Committee chairs are always pivotal because they control the agendas of their respective committees. Many House and Senate committees are delegated considerable latitude in legislating within their jurisdiction-or in deciding not to legislate, so that committee members who take responsibility for writing a bill that is reported out of committee are also pivotal. Similarly, majority party leaders are often pivotal, in part because they can control the agenda of each house of Congress (including the amendments that will be considered) and in part because

36. See discussion supra part I and note 14 . 
their positions give them greater access to information about the distribution of preferences in the legislature. Finally, when a bill reaches the floor, its sponsors among the committee and party leadership must induce others to become supporters. This leads to compromises whereby the preferences of moderates determine the content of the final bill, not the position of the most ardent supporters. ${ }^{37}$

A clear grasp of the structure and process of legislative decisionmaking helps clarify answers to several nagging questions broached by critics of an intentionalist approach. Many have criticized intentionalism because legislatures are a "they" not an "it." All 535 voting members have their own preferences over policy and, hence, their own most preferred interpretation of any piece of legislation. Moreover, as social choice theorists have known since Condorcet, majority-rule decisionmaking in the absence of agenda control can be unstable. But these observations do not imply that the concept of statutory intent lacks content. In the first place, that legislators all have different intentions does not imply that they do not or cannot strike bargains in order to construct a common understanding of the intention of a particular statute. Returning to the contract analogy, private agreements always involve at least two parties with conflicting preferences, yet the concept of contractual intent is not regarded as problematic. The number of legislators does not change the basic dynamic of policymaking: in the United States, it is Congress as a whole that makes laws, not individual members of Congress. The fact that a particular agreement about intention might be defeated by another intention in a majority rule process with no agenda control does not mean that an enacted bill lacks meaning, just as a collective bargaining agreement does not lack meaning because a majority of union members might vote for an alternative that was not presented to them. To deny that a single, common intention for a statute is possible is to deny as well that Congress can legislate or that private parties can contract, a claim that is patently false. ${ }^{39}$

Critics of intentionalism also have argued that, although a common understanding of intention may be possible, the members of an enacting coalition show no evidence that they share a common understanding. Positive theory offers insights into this criticism as well. Returning for a moment to the contracting analogy, collective enterprises-such as corporations-are fully capable of entering into contracts. When interpretive disputes arise between

37. The centralizing tendency in majority-rule processes is captured in the "median voter" theorem for votes over one-dimensional policies (such as the appropriations for a program) and by the concept of the "win set" in multidimensional policy votes. Previously, we have used both models to discuss statutory interpretation. For a one-dimensional exposition, see McNollgast, supra note 10, and for two dimensions, see McCubbins et al., supra note 16.

38. See generally Eskridge \& Frickey, supra note 4; Kenneth A. Shepsle, Congress is a "They," Not an "It": Legislative Intent as Oxymoron, 12 INT'L REV. L. \& ECON. 239 (1992); Sunstein, supra note 4.

39. Posner makes the same argument, stating: "Institutions act purposively, therefore they have purposes. A document can manifest a single purpose even though those who drafted and approved it had a variety of private motives and expectations." Richard A. Posner, Legal Formalism, Legal Realism, and the Interpretation of Statutes and the Constitution, 37 CASE W. RES. L. REV. 179, 196 (1986-87). 
corporate parties to a contract, the courts typically ascertain the agreement of the parties by examining the statements of each party's chief negotiating officers, regardless of what a particular shareholder or other employee might have thought about the contract. ${ }^{40}$ Corporations employ agents to negotiate on their behalf; analogously, legislatures employ agents at various points in the legislative process, empowering those agents to act in the name of the collective. Sometimes these agents are subsequently overruled, in which case the negation of their actions provides informative signals about legislative intent. Conversely, when they are not overruled, their statements and actions, made in their capacity as agents of the collective, provide information about legislative intent. Moreover, these statements are more informative than the statements and actions of other legislators who were not delegated special responsibilities at these key points in the legislative process.

The instability of social decisions in majority rule institutions has produced another line of criticism. ${ }^{41}$ The most radical of these criticisms argues that social decisions are "incoherent" or meaningless-devoid of any real measure of social "preference" in the populist sense. In the first place, the instability results indicate nothing of this sort. ${ }^{42}$ Rather, they illustrate that social choices need not be transitive. This is far from saying that social choices will be chaotic. In the second place, the structure and process of legislative decisionmaking, once established, leads to policy choices that are structurally stable. ${ }^{43}$ Choices over structure and process are neither random nor unstable, but are chosen by members of the majority party in each legislative chamber to establish an order of business that is regarded as desirable by a majority of legislators. ${ }^{44}$

The details of the rules and procedures under which a bill is considered matter a great deal in determining whose preferences are influential in policymaking. To see this, suppose that the House is considering legislation under a closed rule, that is, no amendments to the committee's bill are allowed. A closed rule gives great power to the members of the committee that brought the bill to the floor. If the proposed rule blocks consideration of amendments that would significantly change the committee's reported bill, other members realize this and would be unlikely to vote for the rule unless they found the committee's proposal not only acceptable but preferable to the outcome they would expect from a less restricted agenda. If the committee's proposal is

40. We are indebted to William Eskridge for pointing out this analogy to us.

41. The most famous of these is KENNETH J. ARROW, SOCIAL CHOICE AND INDIVIDUAL VALUES (1963).

42. For generalizations and interpretations of the Arrovian social choice paradoxes, see THOMAS SCHWARTZ, THE LOGIC OF COLlECTIVE CHOICE (1986).

43. Kenneth Shepsle, Institutional Arrangements and Equilibrium in Multidimensional Voting Models, 23 AM. J. POL. SCI. 27 (1979). But see William Riker, Implications from the Disequilibrium of Majority Rule for the Study of Institutions, 74 AM. POL. SCI. REV. 432 (1980).

44. On the design of legislative structure, see GARY W. COX \& MATHEW D. MCCubBins, legislative leviathan: CONgressional Parties IN tHe U.S. House (1992); Kiewiet \& McCubbins, supra note 34; Barry R. Weingast \& William Marshall, The Industrial Organization of Congress; or, Why Legislatures, Like Firms, Are Not Organized as Markets, 96 J. POL. ECON. 132 (1988). 
considered under a rule that allows important amendments to be offered against the committee's proposal, other members of Congress outside the originating committee can be pivotal. The leadership of the majority party is likely to be influential because, through the Rules Committee, it can decide which amendments will be considered and the order in which they will be introduced. Likewise, if an important amendment is adopted, the winning margin may be supplied by members of the minority party, in which case those members can be pivotal.

In general, two bills that follow precisely the same legislative path will not be equally influenced by each member of the enacting coalition even if the enacting coalitions are identical. One reason is that neither members' preferences nor knowledge about the effects of a proposal will be distributed identically for two pieces of legislation. Another reason is that within the originating committee, different members will assume the role of gatekeeper by taking the lead in writing and shepherding through the legislation. Still another reason is that the centrists on the floor-the marginal members of the coalition-will have different knowledge about different bills, and different stakes in them. These differences will affect the extent to which they will force a bill's more ardent sponsors to compromise.

While identifying the members of the enacting coalition and the weights accorded their preferences in the bargain can be difficult ex post, identifying members who were excluded from the enacting coalition is usually easy. Members who voted against the legislation in key votes, who filed minority reports against the legislation in committee, and who offered rejected amendments to kill or gut the legislation should be regarded as outside the enacting coalition, even if they voted in favor of the bill on final passage. Likewise, pivotal members whose legislative language is subsequently altered can be regarded as having a different intent from that of the enacting coalition which eventually adopted the legislation. Their preferences should be accorded no weight in any interpretive method, except that amendments rejected by the enacting coalition yield further evidence about the dimensions of the bargain struck among its supporters. A similar argument applies when the president vetoes legislation and both houses vote to override the veto, or when key votes are all so lopsided that a veto is likely to be overridden. In this case, the president's preferences on the bill can be ignored.

\section{B. The Economics of Signaling: Reading the Legislative History}

Solving the puzzle of intention entails not just identifying the pivotal members of the enacting coalition, but ascertaining their preferences and agreements. The hazard associated with ascertaining preferences and agreements is that the legislative process is rife with opportunities for strategic behavior. In other words, members have many opportunities to misrepresent their own interests and the intent of a bill. If one cannot distinguish between inaccurate and truthful representations, knowing who was pivotal may not be useful in 
identifying legislative intent. This fact has been a major source of criticism of the intentionalist approach. ${ }^{45}$

One opportunity for strategic behavior on the part of legislators arises from the collective action problem within Congress. Every stage in the legislative process is susceptible to manipulation by strategic actors. For example, amendments can be offered in committee or on the floor that are designed not to change the proposed policy but to kill it. Hence, voting on amendments can be strategic, intended to burden a bill with objectionable amendments so that those who originally favored the bill end up rejecting the amended version. Likewise, extreme statements concerning the intent of legislation can be inserted into the record to move public opinion, to demonstrate fealty to a particular interest, or to put pressure on other members to change their positions.

A second form of strategic behavior arises from the delegation problem. For example, members of Congress and the president might look ahead to the implementation of a statute and its interpretations by the courts. They may be able to anticipate how agencies will choose actions and how courts will interpret statutes in reviewing agency actions. The possibility of influencing these subsequent decisions could lead members of Congress and the president to take independent actions outside the confines of the enacting coalition's bargain. At every stage in legislative bargaining, members of Congress and the president have an incentive to try to twist subsequent interpretations of the bargain in their favor through strategic behavior. Consequently, statements by the president, lobbyists, or members of Congress, either in hearings, debates, or minority reports, when made outside the context of an actor's formal role as a pivotal player, do not represent the collective agreement and should be accorded no weight in the interpretation of the statute.

So how can the legislative history of a statute reveal legislative intent? The fundamental problem, of course, is that citizens, judges, and bureaucrats are uncertain about legislative intent. There is nothing unique about this problem. People frequently are uncertain about the consequences of the decisions they make. Nonetheless, all but the most existentially paralyzed still make decisions and take actions.

The economic theory of decisions under uncertainty begins with the decisionmaker's beliefs about the likelihood of feasible outcomes: a set of probabilities, summing to one, is assigned to the elements of a set of mutually exclusive interpretations. In other words, the decisionmaker assigns weights subjectively to each of the outcomes that could logically follow from a feasible action. We expect people to make use of all of their experiences to make the most "informed" choice. Thus, we expect a person to try to learn-to adjust beliefs about a decision based on inferences drawn from new experiences. But no matter how much experience an individual may have-including events

45. See Eskridge \& Frickey, supra note 4; Sunstein, supra note 4. 
observed and signals received from other people-some uncertainty about the consequences of any action will remain.

A little statistical decision theory helps to clarify the general issue of the value of new information. A judge may believe that any one of four mutually exclusive interpretations- $A, B, C$, or $D-$ of a clause in an act are plausible. Based on Step One, a "plain meaning" reading, and Step Two, a consideration of the purpose and structure of the organic act, ${ }^{46}$ the judge concludes that $A$ is the most plausible interpretation, but that the other three are not ruled out and are all about equally likely. Writing the probability that an interpretation is correct as $\mathrm{P}(\mathrm{i})$, where $\mathrm{i}=A, B, C$, or $D$, these beliefs might be represented as $P(A)=.4$, and $P(B)=P(C)=P(D)=.2$. For ease of analysis, assume that the judge has no personal preference among these alternatives, and so cares only about democratic legitimacy in picking among the alternatives.

If interpretive investigation ends at this point, the decision of the judge depends on the normative context of the decision. The judge may believe that the best interpretive principle is to maximize the probability that the legislative intent is implemented, which implies picking $A$. However, this choice will, on average, be incorrect sixty percent of the time. Alternatively, the judge might believe in narrow textualism, and so refuse to apply the statute whenever the intent of the enacting coalition is not stated in the text with sufficient clarity to remove most uncertainty. This amounts to rejecting all statutes that are unclear, in favor of another alternative, the status quo ante. Picking the status quo when a legislative coalition has taken costly action to enact a statute-however vague it may be-fails a very basic rationality test. Rational actors would not expend effort and resources to enact vacuous legislation that does not affect the status quo. Hence, the status quo is certain not to be the intent of the legislation.

Suppose that the judge proceeds to read the legislative history and finds that at some point in the process all four interpretations were attributed to the statute. This discovery might be helpful in structuring the judge's opinion, for it would produce quotes and citations to buttress whatever choice was made. But the judge would be no better informed about the actual agreement in the statute. However, suppose that further examination reveals that $A$ was inserted in the record after the vote was taken as an extension of the remarks of a legislator, $B$ was stated as the explanation for a vote against the bill by one of its opponents, $C$ was inserted by a legislator as an explanation of why certain constituents support it, and $D$ was offered by the floor manager of the bill acting as the agent of the House (for example, in response to a question about the implications of some language in the report of the House-Senate Conference Committee that produced the final version of the bill). For reasons discussed in more detail below, the first three statements are all likely to be "cheap talk," strategic statements for which the legislators making them are not held accountable, and thus are unlikely to be informative as to the true intent of the

46. See supra text accompanying notes 5-6. 
legislation. But $D$ is consequential: the legislator making that statement did so as an appointed agent of the legislative majority that passed the chamber's version of the statute. A legislator acting as an agent for the majority can be subject to sanctions and loss of reputation if this interpretation is not truthful. Thus, our jurist would be driven to conclude that alternative $D$ is now the interpretation that is most likely to be correct.

The type of learning described above does not necessarily lead to a choice that is certain to be correct, but in a probabilistic sense it never produces a worse choice. Thus, the judge might conclude that the chance that a floor manager answers a question correctly is only .9 , based on past experience with reading legislative histories. The statement of the floor manager raises the probability that $D$ is the true intent to .69. Applying Bayes Rule for updating probabilities and assuming that all forms of cheap talk are equally unreliable and so uninformative, after the statements have been observed, the chance that $A$ is correct has fallen to (roughly) fifteen percent: persisting in picking it (and ignoring the legislative history) will be wrong eighty-five percent of the time. ${ }^{47}$

To change the example, suppose that both $C$ and $D$ are statements by a floor manager, one in the House and one in the Senate, in response to the same question. Still applying the rule of thumb that floor managers lie ten percent of the time, four possibilities remain: (1) Both are prevaricating, with probability .01 (the product of .1 and .1); (2) $C$ is truthful and $D$ is false, with probability .09 (the product of .1 and .9); (3) $C$ is false and $D$ is true, also with probability .09; and (4) both managers are answering truthfully, but the enacting coalition had an unresolved, unrecognized disagreement, which is the most likely case with probability .81 . In this case, persisting with $\mathrm{A}$ is clearly incorrect-applying Bayes Rule the probability that it is the right interpretation is .011! $C$ and $D$ are each likely to be correct with probability .492 , so the judge is still more likely to be wrong than to be right with either choice. Again, additional normative principles may be invoked to favor one choice over another. For example, one interpretation may amount to a private bill for a special interest, or one may be more consistent with other law that the new statute was not enacted to repeal, or one choice may be the decision of the implementing agency, which can be accorded deference under broad delegation. Or the judge might conclude that if no interpretation is more likely to be correct than incorrect, the statute should be declared unenforceable because it is an unconstitutionally vague delegation. Regardless of which normative principles are used at this last step in the process, however, consulting the legislative history is a valuable activity as long as the statute is not clear. Reviewing the legislative history can increase the chance that the judge is basing an interpretation on the intent of the statute, and eliminate some cases in which the judge regards no interpretation as very likely.

47. Bayes Rule provides:

$P($ event $\mid$ data $)=$

$P($ data levent) $P($ event $)$

$\overline{\mathrm{P}(\text { data } \mid \text { event }) \mathrm{P}(\text { event })+\mathrm{P}(\text { data } \mid \text { not event }) \mathrm{P}(\text { not event })}$ 
The point of view expressed here is subtly at odds with a great deal of literature on statutory interpretation. ${ }^{48}$ The fact that an intelligent, theoretically grounded review of a legislative history does not necessarily reveal legislative intent with perfect certainty is far from fatal to our argument. Theoretically well-grounded interpretations of legislative signals will produce better information than poorly grounded readings of the history or than a decision to ignore all of the history because some of it is uninformative. Furthermore, decisions based on better information can be no worse, and sometimes will be better, than decisions based on worse information. In short, an interpretive method that leads judges to pick $D$ in the first example, or to invoke other criteria to select between $C$ and $D$ in the second example, is preferable to a method that would pick $\mathrm{A}$ in both instances.

The economics of signaling provides general lessons about how people learn from observing the actions of others. ${ }^{49}$ We presume that members of the enacting coalition are better informed about the intent of the legislative bargain to which they are parties than are bureaucrats or jurists looking back at that bargain. Thus, one precondition for learning is satisfied; if bureaucrats and jurists can identify informative actions and messages coming from coalition members, they can learn about legislative intent.

The economics of signaling also suggests that an action is informative if it is taken by an informed person who pays a fee, expends effort, or foregoes some valuable alternative activity in order to take the action. The logic of this lesson is basically the old adage that "actions speak louder than words." Opportunity costs cannot be recovered. Thus, in the legislative context, members of the enacting coalition will not take actions that they believe will make them worse off than doing nothing (after accounting for the cost of the actions themselves). For example, legislators have many demands on their time, yet still participate in debates in committee and on the floor, rather than (as the rules allow) mailing in some well-chosen rhetoric after the die is cast. Why don't members simply shut up and vote? One explanation is that much floor debate actually consists of members expressing specific concerns about a bill, for which they demand explanations from the floor manager. Judges can gain insight into the intent of

48. Notable exceptions are Shapiro and Posner. Shapiro, in favoring deference to agencies when multiple interpretations are plausible, expresses hope that "the stubborn persistence of reality may block the autonomous tendency of the law to pretend that statutes have far more fixed meanings than most of them actually do." SHAPIRO, supra note 12, at 172 . Posner, in a far more reaching statement of indeterminacy in legal analysis, adopts a position much like ours: "Legal reasoning is not a branch of exact inquiry in an interesting sense, although continued progress in the economic analysis of the law may compel a modification of this conclusion eventually." Richard A. Posner, The Jurisprudence of Skepticism, 86 MICH. L. REV. 827, 858-59 (1988).

49. On the economics of signaling, see JefFrey S. BANKS, Signaling GAMES In POLITICAL SCIENCE, New York: HARDWOOd ACADEMIC PuBlishers (1991); Randall L. Calvert, The Value of Biased Information: A Rational Choice Model of Political Advice, 47 J. POL. 530 (1985); Vincent P. Crawford \& Joel Sobel, Strategic Information Transmission, 50 ECONOMETRICA 1431 (1982); Arthur Lupia, Busy Voters, Agenda Control and the Power of Information, 86 AM. POL. SCI. REV. 390 (1992). See also Arthur Lupia \& Mathew D. McCubbins, Designing Bureaucratic Accountability, 57 LAW \& CONTEMP. PROBS. 91 (Winter 1994). 
a bill from observing the questions asked of the floor manager by members who ultimately support it.

Generally, an observer can learn from the actions of coalition members in the sense that the observer knows that some actions will not be worth taking; the greater the cost that an actor must bear to take an action, the greater the expected benefit resulting from the action must be to justify it. Thus, the observer can effectively exclude those states of the world where the observed actions would have left the actor-the informed party-worse off than taking no action.

How is it that judges or agency personnel can learn from costly actions and accountable messages? Observing costly actions can help judges exclude some alternative interpretations. For example, interpretations of a statute that were rejected as amendments or alternatives to a bill cannot become part of a valid interpretation of the statutory intent. By rejecting an alternative to the enacted language, members of the enacting coalition take costly actions that inform observers about the meaning of what is not rejected. To the extent that explicit exclusions or rejections of alternatives are sustained at future stages, such costly actions provide meaningful signals about what was not intended by the coalition. That which is rejected is both the strict textual element of the bill, and an entire family of extensions of the original bill that are dependent on some aspect of the rejected alternative. Any action chosen by an agency (under the statute) in response to some unanticipated contingency that implements or extends a rejected alternative must itself be invalid.

Learning from legislative statements is similar. Whether a statement by a legislator is subject to punishment if the statement is false or misleading depends on the circumstances. For a legislature to work effectively, its members need to be able to rely upon the truthfulness of some statements. The structure of Congress-party organization and committees-reflects in part an attempt to achieve efficiencies through delegation and specialization. In order for the legislative system to work, members must be able to rely on a member acting as an agent of the entire body.

The ability to rely on each other, given the diversity of interests among political actors, cannot simply be assumed because it is collectively desirable, for each member will experience circumstances in which personal benefits can be derived from abrogating the norm of truthful revelation. To enforce this norm requires that the legislative body have the will and means to punish members who are not truthful when acting as agents for the entire body.

In practice, political actors have two routes to enforce truthfulness. First, members who prevaricate can be and occasionally are removed from gatekeeping positions, such as party leadership or committee chairs. Second, because Congress passes a very large number of legislative provisions each year, the same member is likely to be in a position of delegated authority on many occasions. To succeed in accomplishing numerous legislative objectives over a lifetime in politics, a legislator will find it valuable to develop a reputation for not taking strategic advantage when acting as an agent for other members. Thus, a 
behavioral norm whereby legislators behave truthfully in their capacities as representatives of a coalition, but strategically in their individual roles as representatives of their constituencies, is self-enforcing.

By contrast, a behavioral norm that members behave truthfully and nonstrategically when making an advocacy statement about a policy proposal is not enforceable, in part because other legislators have no way of knowing a legislator's true preferences. Moreover, because advocacy statements can be aimed at constituents, contributors, and others outside the government, legislators would not find it in their collective interests to devise a system of rewards and punishments that demanded only truthful statements of personal preference. Consequently, as Sunstein points out, much floor debate "reflects little, if any general congressional will." 50

These principles ensure that the findings, interpretations, and proposals of agents of the majority, as reported to the House and Senate for review, are meaningful signals about the legislative intent of the committee majority. Statements by these members in their express capacity as agents of the ultimate majority coalition for the bill on the floor are subject to penalties for lying. The willingness of the floor to give members of a committee gatekeeping authority over future bills as well as the committee's efforts in crafting a bill are at risk if they misconstrue the meaning of the bill that they propose. Under the reasonable assumption that maintaining a good reputation with one's peers is a necessary condition for retaining a position of trust, a member has an incentive not to misrepresent legislative bargains when acting in an official capacity as agent for the majority.

Suppose, for example, that legislators who later vote in favor of a bill ask specific questions of the floor manager. The floor manager is a member who has been appointed by the majority coalition in the legislature as its agent. One service that the agent is expected to provide is answering questions about the scope and intent of the bill. Why should anyone believe the floor manager's answers? The floor manager's institutional role creates an opportunity to behave strategically-possibly, to tell lies. The economics of signaling suggest that the answers are believable only to the extent that the floor manager faces penalties for telling lies. If agents face penalties for lying, some lies will not be worth telling (those lies for which the expected gain from lying is less than the penalty). Moreover, if agencies and the court actually interpret laws in accordance with the answers of floor managers, bills will not pass if a majority does not like the answer; therefore, floor managers will take this anticipated response into account when formulating their answers. As a result, an outside observer can learn from the behavior of coalition members, in this case statements on the record about the bill by members who have been appointed to fill important institutional roles in the legislative process. This reasoning applies not only to

50. Sunstein, supra note 4 , at 429 . 
floor managers, but also to committee members who were responsible for writing the committee report or the special rule under which the bill was considered. These members can be held accountable by other coalition members for their statements because they face penalties for lying.

When members of Congress or the president do not face disincentives to act strategically, they probably will. Presidential signing statements, for example, cannot be rejected or overturned by Congress, and are not negotiated with members of the legislative coalition. Hence, the potential for unchecked opportunistic behavior by the president is great. Presidents cannot easily be held accountable for these statements by other coalition members. We therefore expect presidents to act strategically in formulating signing statements. Our theory of statutory interpretation concludes that observers will be unable to learn what the president believes about the coalition's bargain from these statements.

Legislation proposed by the president also does not represent a negotiated agreement. Hence, the president is free to behave strategically in making proposals to Congress. Nevertheless, if Congress enacts language proposed by the president, the courts should consider the president's explanations of the proposal when it was submitted, for if Congress were not in agreement with these statements, it could have amended the language or otherwise contradicted this interpretation during its deliberations.

Likewise, members of Congress acting other than as designated agents of the enacting coalition cannot be held accountable by the majority for their actions and statements. Their incentives to act strategically will run unchecked, and, again, our approach suggests that their statements should be discounted. Thus, a statement by a member acting as an individual, and minority views and reports, should carry no weight in statutory interpretation. Through PPT we learn that talk is cheap. Only when the majority exerts effort to monitor and to constrain talk should statements be considered relevant for statutory interpretation, and then only to the extent that such talk is not directly contradicted by costly, consequential action, that is, by voting behavior.

Professor Sunstein provides a marvelous example of congressional cheap talk, quoting from the Congressional Record a statement made by Representative Heckler:

Mr. Speaker, having received unanimous consent to extend my remarks in the RECORD, I would like to indicate that I am not really speaking these words . ... As a matter of fact, I am back in my office typing this out on my own hot little typewriter .... Such is the pretense of the House that it would have been easy to just quietly include these remarks in the RECORD, issue a brave press release, and convince thousands of cheering constituents that I was there fighting every step of the way, influencing the course of history in the heat of debate. ${ }^{\mathrm{s}}$

51. Id. at 429 n.86. 
Representative Heckler, Justice Scalia, and Professor Sunstein thus have good reason to ignore most of what is said in congressional debates. Our point is only that not all talk is cheap and that, moreover, we know when it is not. To illustrate this point, we examine the legislative histories of two statutes to evaluate the validity of the way they were interpreted by the courts.

\section{IV}

\section{INTERPRETATIONS OF NEPA AND THE CLEAN AIR ACT AMENDMENTS}

We have shown that PPT provides several important insights for distinguishing relevant from irrelevant signals emanating from the legislative process. Judges and other observers who seek to uncover the original intent of legislation should focus their attention on the choices coalition members make and the messages they compose when misrepresenting their intentions could be costly. Other information is likely to be unreliable, and therefore should be discounted heavily or ignored altogether.

This section applies the logic of our approach to a controversial court decision from the 1970s: Judge Wright's 1971 opinion for the District of Columbia Circuit in Calvert Cliffs Coordinating Committee v. Atomic Energy Commission, ${ }^{52}$ which clarified the applicability of the NEPA to the AEC. This Section compares this decision to a roughly contemporary decision by Judge Pratt in Sierra Club v. Ruckleshaus, ${ }^{53}$ which required the EPA to apply the Prevention of Significant Deterioration ("PSD") ambient air quality standard for regulating pollution in pristine areas according to the Clean Air Act of 1970. Both decisions, critics charge, pushed policy beyond the spirit of the bargain struck by members of the enacting coalition. By reexamining these two decisions, this section illustrates the practical utility of applying the positive perspective on legislative bargaining that we have developed in this article.

\section{A. Sierra Club}

In a previous article ${ }^{54}$ we provided the evidence from which we conclude that in Sierra Club, Judge Pratt interpreted the Clean Air Act of 1970 (the "Act") incorrectly because he relied on material in the legislative history that did not reflect the agreement of the enacting coalition. ${ }^{55}$ The issue in the Sierra case was whether state implementation plans under the Act must include provisions to protect clean air areas from significant deterioration. ${ }^{56}$ Briefly, the

52. 449 F.2d 1109 (D.C. Cir. 1971).

53. 334 F. Supp. 253 (D.D.C. 1972).

54. McNollgast, supra note 13 .

55. See generally Spiller, supra note 22; Brian Marks, A Model of Judicial Influence on Congressional Policymaking: Grove City College v. Bell (1990) (unpublished manuscript, on file with the Hoover Institution Working Paper in Political Science P-88-7); Spiller \& Gely, supra note 31.

56. The court found that the 1970 Act did require that SIPS provide for prevention of significant deterioration or "degradation." Judge Pratt's decision was based on a claim that PSD was "already established" as a policy prior to the 1970 Act and that the new act's stated goal was to enhance and 
ambiguity in the Act arose because of an apparent contradiction in two provisions. The preface of the Act was unqualified, stating that the purpose of the Act was to "protect and enhance the quality of the Nation's air resources."57 However, subsequent sections of the Act only authorized the EPA to set ambient air quality standards that were "requisite to protect the public welfare from any known or anticipated adverse effects associated with the presence of such air pollution in the ambient air."58 More stringent standards, if any, could only be set by the states. The Act went on to require relatively stringent emissions standards for new stationary sources in pristine areas, but nowhere did it state explicitly that the ambient air quality standard in these areas was to be the current state of air quality, even if some degradation were possible without producing adverse effects. ${ }^{59}$

improve air quality. R. Shep Melnick, Regulation and the Courts: The Case of THE Clean AIR ACT 77 (1983). His claim that PSD was existing policy was based on five pieces of evidence, which according to Melnick were:

1. A 1969 National Air Pollution Control Administration ("NAPCA") guideline announcing that state air quality standards that "result in significant deterioration of air quality" conflict with the "protect and enhance" goal of the 1967 Clean Air Act.

This is an example of costly but irrelevant action. The Statement is about the 1967 Act, not the 1970 Act. The 1967 Act did not give the federal government authority to set either primary or secondary national ambient air quality standards, or new source performance standards. Hence the statement of "policy" was largely without teeth, according to Melnick.

2. A 1970 statement by HEW officials that Nixon Administration proposals to amend the 1967 Act were consistent with the NAPCA guideline.

This qualifies as cheap talk because statements about the effect of a legislative proposal by executive branch officials are not credible if those officials cannot be held accountable for their statements of opinion. The NAPCA guideline, as noted above, carried no sanctions to enforce "policy." Hence, it was only advisory. Hence, the cited statement by HEW officials need only imply that they agreed that "dirtying clean air baaaad. wouldn't be prudent. not gonna do it."

3. A 1970 Senate report stating that the EPA should reject SIPS that don't provide "to the maximum extent practicable, for the continued maintenance of [pristine air areas'] ambient air quality."

This reasoning constitutes costly action, but blatantly misread by Judge Pratt. As we argued in our previous work, Judge Pratt did not cite the full passage, which goes on to state that "deterioration of air quality should not be permitted except under circumstances where there is no available alternative." Clearly, the Senate Environment and Public Works Committee anticipated that there would be circumstances in which significant deterioration of pristine air areas would be justifiable, and specified what to do in those circumstances.

4. An EPA proposed guideline from 1971 (later withdrawn) that national air quality standards "shall not be considered in any manner to allow significant deterioration of existing air quality in any portion of any state."

This constitutes costly action by EPA both in terms of proposing such a standard and in the fact that it was withdrawn. We can make inferences from what proposals are rejected about how to interpret what is accepted. Again, the withdrawl of this passage, like the Senate report discussed in point 3 above, suggests that actors involved in composing and implementing the Act believed the Act did not require PSD, but rather permitted pristine areas to be degraded under some circumstances.

5. Statements by committee members in oversight hearings in 1972 linking the "protect and enhance" language of the 1970 Act to "PSD."

This is blatant cheap talk: No member can be held accountable by peers for policy statements made during oversight hearings, becausee no votes are taken and no common positions are determined. Id. at 77-78.

57. 42 U.S.C. § 7401(b)(1) (1988).

58. MELNICK, supra note 56, at 78-79.

59. For a full discussion of these issues, see MELNICK, supra note 56. On this general problem, see Bruce A. Ackerman \& William T. Hassler, Clean CoAl, DirTy AIR (1981); E. Donald Elliot et 
In deciding Sierra Club, Judge Pratt concluded that the general statement of purpose in the preface overrode the implied qualifications in subsequent sections. This interpretation ignored the process by which a legislative majority was created to pass the bill. Whereas ardent supporters of tough environmental laws drafted the initial legislation, including the unqualified preface, numerous compromises were required in specific sections of the bill to obtain the support of a legislative majority. One group that eventually joined the enacting coalition was composed of legislators from undeveloped pristine regions. These representatives wanted the Act to be sufficiently flexible that it would permit economic growth in these areas. While they were willing to accept demanding emissions standards for new sources-the "best available control technology"-they were not willing to accept the requirement that air quality not be permitted the slightest bit of degradation. By insisting upon the PSD standard, Judge Pratt failed to honor the preferences of pivotal members of the enacting coalition, and thereby overturned their legislative agreement.

Significantly, the problem in Sierra Club could not be solved by reference to a "plain meaning" or "narrow construction" interpretive principle. The statute is quite clear in stating that air quality is to be regulated by the EPA throughout the country, so pristine areas could not be construed as being exempt. The problem results from a contradiction in the quite clear meanings of two sections of the same act. One has to choose between these sections, and PPT provides direction as to which one ought to have precedence if the point is to enforce the law as Congress intended. Judge Pratt wrote a new statute by ruling that the unqualified preface trumped the qualifications in subsequent sections.

\section{B. Calvert Cliffs}

The Calvert Cliffs case illustrates more clearly how judges can use the positive theory of the legislative process to uncover the intentions of a statute's enacting coalition. NEPA imposed a duty on all federal agencies and departments to establish procedures through which environmental issues could be raised and considered whenever an agency seeks to take a significant action or make a recommendation to Congress. In Calvert Cliffs, the D.C. Court of Appeals was asked to evaluate rules promulgated by the AEC to implement NEPA. While the language in the Act clearly provided that NEPA applied to all federal entities, it was less clear as to how the Act was to be implemented. One area of ambiguity was the effect of the Act on ongoing regulatory activities and licensing procedures that were being conducted in discrete stages, such as the process for granting construction permits and operating licenses for nuclear power plants.

Judge Wright made four primary findings in his decision, all of which concerned the degree of discretion available to the AEC in the form and timing 


\section{of its implementation of NEPA. ${ }^{60}$ First, Wright found that NEPA imposed a}

60. The court addressed four specific questions regarding the AEC's implementation of NEPA:

1. The AEC under the Atomic Energy Act of $\mathbf{1 9 5 4}$ appoints a hearing board to review applications for and make recommendations to the commission on operating licenses and construction permits for nuclear power plants. Must the hearing board explicitly consider environmental issues in its hearing process even if no environmental issues are raised before it by professional staff or outside parties?

The court held that the hearing board must explicitly consider environmental issues regardless of what is or is not raised in the public hearing. In citing the evidence which supported the holding, Judge Wright noted that in the Act Congress used two different standards for implementation of various requirements-"fullest extent possible," in Sect. 102, and "all practicable means consistent with other essential considerations," in Sect. 101(b). This costly action on the part of Congress suggests that the procedural requirements of Sect. 102, including that the detailed statement of environmental impact "accompany" a proposal throughout the regulatory process, means that the statement must be considered "to the fullest extent possible" at every stage. Judge Wright further noted that House and Senate conferees on NEPA had reported that the "fullest extent possible" language meant that "no agency shall use an excessively narrow construction of its existing statutuory authorizations to avoid compliance" with the goals of the act.

2. NEPA became law on January 1,1970 but did not specify a timetable for implementation. AEC issued a final rule implementing NEPA on December 3, 1970, which stipulated that nonradiological environmental issues could not be raised in any hearing (construction permit or operating license) if public notice of the hearing appeared in the Federal Register before March 4, 1971. Could the AEC prohibit its hearing boards from considering nonradiological environmental issues in these cases?

The court held that agencies must seek means to comply with NEPA immediately. On-going regulatory processes, such as licensing or permitting investigations that began before NEPA was enacted, should be assessed to uncover what options are available to incorporate environmental concerns, "balanced" against the costs of mid-course corrections. The earlier on a project is in a regulatory process, the greater should be the scope of environment-protecting actions that might be justified in a "balanced" review.

In support of its holding, the court noted that Congress has often specified implementation dates or "grandfather" clauses when passing new regulatory legislation. They did not do so in this case, thus the language of the statute permits no justification for delaying consideration of environmental issues. The law sets a substantive standard requiring that environmental issues be protected by "all practicable means consistent with other essential considerations" and that on environmental questions, alternative courses of action be spelled out by the agency "to the fullest extent possible."

3. The AEC further prohibited its hearing boards from conducting independent investigations and balancing evaluations of certain environmental issues for which other agencies have previously certified that minimum statutory standards have been met by applicants. Could the AEC do this?

The court found that under NEPA, agencies are not limited by other agency's findings that a project has met minimum statutory standards. The AEC can impose more stringent environmental standards if warranted through an explicit "balancing" consideration; therefore, the AEC must demonstrate that it considered the possible effects of more stringent environmental standards.

According to Judge Wright, the "plain language of Section 104 of NEPA and [the Water Quality Improvement Act of 1970]" makes clear that agencies are not limited in their implementation of NEPA by other agency's findings. The judge cited statements made by Sen. Jackson during Senate debate over the NEPA conference report (140, notes 35 and 37), where he clarified that NEPA would not relieve agencies of implementing more stringent requirements established under other statutes (such as WQIA). Jackson, as floor manager for NEPA, noted that Sect. 104 was added to reassure supporters of the WOIA that NEPA would not undercut its requirements. Finally, Judge Wright also cited the section-by-section analysis of NEPA submitted by conferees to the Senate, which said NEPA procedures could not substitute for more restrictive procedures in other acts. The judge inferred that where other procedures were less restrictive, NEPA could require greater environmental protections through a balancing analysis.

4. Under the Atomic Energy Act of 1954, the AEC conducts two stages of review of nuclear power plants-for construction permits and for operating licenses. Could the AEC refuse to consider environmental factors or require modifications in proposed facilities in between these regulatory stages if the construction permit was issued before NEPA?

The court found that "A full NEPA consideration of alterations in the original plan of a facility $\ldots$ is both important and appropriate well before the operating license proceedings. It is not duplicative 
nondiscretionary duty on the AEC to consider environmental issues explicitly at every regulatory step, even when no intervenor has raised any environmental concerns. $^{61}$ Second, he found that the AEC was required by NEPA to begin considering environmental issues surrounding the construction and operation of nuclear power plants as soon as possible, even if a plant had already received a construction permit, as long as it had not yet received an operating license. ${ }^{62}$ Third, Wright declared that NEPA's sections 104 and 105 stipulations preserving the environmental obligations imposed by other statutes were meant to create minimum standards that the AEC must meet in its environmental reviews, rather than limiting the agency's scope for regulatory action. ${ }^{63}$ Fourth, the judge found that NEPA required federal licensing authorities such as the AEC to consider ordering backfitting modifications to facilities when the environmental benefits outweighed the costs. ${ }^{64}$

In each case, Judge Wright's findings are supported by costly actions on the part of members of the enacting coalition, although Wright also cites "cheap talk" in some instances. First, the wording of section $102(2)(c)$, requiring that agencies include a "detailed statement" of environmental impacts in their administrative record for every significant agency action, arises from a compromise within the Senate. The section, as first written and passed by the Senate in S. 1075, had required agencies to make an environmental "finding" at every stage. However, a dispute arose between Senator Jackson (D.-Wash), primary author of S. 1075 in the Senate Interior Committee, and Senator Muskie (D.-Maine) of the Senate Environment and Public Works Committee, over the relationship between NEPA and pollution control requirements under the Water Quality Improvement Act of 1970. That dispute was settled when the Senate amended S. 1075 , prior to appointing a conference committee, to replace the "finding" requirement with the "detailed statement" requirement. The Senate then instructed its conferees to preserve that language change to insure that NEPA would not permit agencies to circumvent the legal requirements imposed by the Water Quality Improvement Act or other acts with similar, specific environmental standards.

[of what would be done in the operating license proceedings] if environmental issues were not considered in granting the construction permit."

Judge Wright noted that the AEC's rules did require the composition of the "detailed statement" in these cases. Judge Wright found that the rules prohibiting the AEC from requiring midcourse corrections in light of the evidence produced by the "detailed statement" of environmental impact were plainly contrary to NEPA's required "balancing." The judge found that the detailed statement requirement is actually an "action-forcing" requirement. The judge cited the Council of Environmental Quality guidelines of April 23, 1971 interpreting section 102(2)(c) as evidence. Those guidelines "urge agencies to employ NEPA procedures to minimize environmental damage, even when approval of particular projects was given before January 1,1970." NEPA designated CEQ as the agency responsible for composing guidelines for agency implementation of the Act. 1971).

61. Calvert Cliffs Coordinating Comm. v. Atomic Energy Comm'n, 449 F.2d 1109, 1112 (D.C.Cir.

62. Id. at 1128.

63. Id. at 1125 .

64. Id. at 1128 . 
The compromise clarified that agencies must meet minimum statutory standards, but must also consider going beyond such minima. Hence, the provision is nondiscretionary; there are no circumstances in which an agency can decline to compose the "detailed statement" and consider its environmental implications in agency decisionmaking. Every agency decision must show evidence that the detailed statement was incorporated as part of the evidence upon which the decision was made.

Second, NEPA set no specific deadline for when agencies must begin giving full force to the Act's environmental requirements, but rather called for agencies to consider environmental issues "to the fullest extent possible," beginning from the Act's effective date, January 1, 1970. Judge Wright noted that the Act did require agencies to notify the president by July 1, 1971, if there were any insuperable statutory barriers to their implementing the Act's requirements. Furthermore, the House conference committee report specifically states that an agency, in reviewing its statutory authorities and reporting conflicts to the president, "shall not construe its existing authority in an unduly narrow manner."65 Judge Wright read these statements to mean that the AEC was obligated to begin immediately to consider environmental issues in all its regulatory endeavors. Hence, even if a plant had already received regulatory approval for construction or operation, the AEC was required to investigate environmental concerns, develop alternative courses of action, and evaluate the costs and benefits of alternatives. Because the stated purpose of the Act was to protect environmental values in a cost-effective manner, this necessarily required the AEC to consider requiring backfitting modifications to plants already approved.

Judge Wright made numerous references to statements made by various members of the enacting coalition in committee hearings and floor debates. Some of these statements are unreliable indices of legislative intent. However, in nearly every case, the "cheap talk" was also accompanied by reference to costly actions. For example, Wright cites a colloquy between Senators Jackson and Muskie discussing the intent of the compromise that led the Senate to change the "finding" requirement of section 102(2)(c) to "detailed statement" and to change section 104 , and a later colloquy in which the two discussed the same portions of the conference report on the bill. ${ }^{66}$ At the same time, Wright also cites the section-by-section analysis of NEPA, for which Jackson asked unanimous consent to have included in the Congressional Record. ${ }^{67}$ Jackson, who was appointed by the Senate to report on the conference committee's proposals (itself a costly action), exposed his own reputation as a good agent for the Senate by this action-subjecting himself to an expected cost for lying.

65. H.R. REP. No. 765, 91st Cong., 1st Sess., at 10 (1969), reprinted in 1969 U.S.C.C.A.N. 2767, 2771.

66. Calvert Cliffs, 449 F.2d at 1125 .

67. Id. at 1126 . 
Furthermore, the Senate itself had repeatedly taken costly actions to clarify the intent of the legislation, through consideration of the original bill, S. 1075, later amendments to the bill, and instructions to its conferees. The colloquies between Jackson and Muskie largely reflect the costly actions taken by members of the enacting coalition in the Senate.

In another passage, Judge Wright cites statements made by Jackson during committee hearings and later in floor debate that NEPA established certain "action-forcing" procedures (such as those of section 102(2)(c)) ${ }^{68}$ However, these statements are also supported by language in the Senate Interior Committee's report on S. 1075 that "stressed the importance of the 'actionforcing' provisions which require full and rigorous consideration of environmental values . ..." ${ }^{99}$ Indeed, at nearly every turn, Judge Wright looks to costly actions taken by House and Senate committees, chamber majorities, or House and Senate conferees to support his interpretations of the Act.

By contrast, the AEC briefs, in arguing for a looser application of NEPA to the agency, rely only on loose interpretations of "cheap talk," such as floor debates. As Judge Wright notes, it is language that "all the members of both houses of Congress must approve or disapprove" that is most meaningful in discerning statutory intent. "The courts should not allow that language to be significantly undercut. In cases such as this one, the most we should do to interpret clear statutory wording is to see that the overriding purpose behind the wording supports its plain meaning." 70

Subsequent legislative action supports our conclusion that Judge Wright correctly interpreted legislative intent, while Judge Pratt did not. In a prior publication, we show that Congress's failure to repeal Sierra Club's requirement of PSD was not for a lack of effort. ${ }^{71}$ In fact, measures were introduced to overturn the PSD requirement in both 1976 and 1977. These measures had had the support of President Nixon and the key decisionmakers in the Senate. In the end, however, the gatekeepers in the House, who had wanted PSD all along but had been forced to sacrifice it to craft a majority for the 1970 legislation, simply would not give up the windfall that Judge Pratt had provided with the Sierra Club decision.

This case illustrates an important principle of the positive theory of the legislative process: The absence of an ex post reaction to a judicially imposed policy does not imply that the judicial interpretation of the original legislation was correct. Rather, it reflects the court's ability to replace the original intent with one of its own under political circumstances in which elected officials cannot reverse. The notion that Congress will correct an interpretive mistake by the court is simply wrong.

68. Id. at 1125 .

69. S. REP. No. 91-296, 91st Cong., 1st Sess. 1113, n.7 (1969).

70. Calvert Cliffs, 449 F.2d at 1125.

71. McCubbins et al., supra note 16 . 
In the case of Calvert Cliffs, Congress appeared partially to reverse Judge Wright's decision. Congress passed legislation amending the Atomic Energy Act of 1954, which permitted the AEC to issue temporary operating licenses for certain nuclear power plants. $^{72}$ This legislation, however, came about not because Judge Wright's interpretation was incorrect, but because the AEC responded to Judge Wright in a manner that Congress did not completely anticipate. Judge Wright ordered the AEC to reconsider its procedures for implementing NEPA. In response, the agency placed a moratorium on new operating licenses.

While this action provided a transitory benefit to the ardent opponents of nuclear power, it went beyond the objectives of the enacting coalition. The purpose of NEPA was to incorporate environmental costs and benefits into the decisions of federal agencies, not to stop all nuclear power or, more generally, to cause government regulatory processes to grind to a halt. Members of the House and Senate successfully negotiated a partial retrenchment of the AEC's response to Calvert Cliffs by passing HR $14655 .^{73}$

\section{$\mathrm{V}$}

\section{CONCLUSION}

PPT can make a significant contribution to a positive and normative theory of statutory interpretation. Positive theory focuses attention on several important features of the legislative process. One is a sharper conceptualization of the notion of "statutory intent," one which maintains that a statute records the agreement of the enacting coalition with respect to the policy adopted. A statute enables members of the enacting coalition to know more precisely the nature of their agreement, and conveys instructions to agencies and courts.

Statutes are most assuredly not embodiments of the preferences of any particular legislator, but a compromise among these preferences. The structure and process of legislative enactment allocate influence to the relevant actors (including the president), and sometimes accord greater weight to one over another, depending on the specific circumstances surrounding the legislation. Consequently, there does not exist a set of weights to be attached to the preferences of members of the enacting coalition that applies in all cases. Nor should equal weight be placed on elements of the legislative history, regardless of how the legislation actually evolved.

Our purpose is to ground statutory interpretation in an accurate, descriptive model of the legislative process. While some of this approach is new-most notably, its language, methods, and mode of analysis-it is firmly rooted in the traditions of statutory interpretation. As with Hart and Sacks, our view involves

72. Pub. L. No. 92-307, 86 Stat. 191, $191-92$ (1972) (codified at 42 U.S.C. $\$ 2242$ (1988)).

73. Id. 
the "attribution of purpose" to legislation. ${ }^{74}$ It also involves the "method of imaginative reconstruction," in which, as Posner says, "the judge should put himself in the shoes of the enacting legislators and figure out how they would have wanted the statute applied." 75 In both cases, our approach provides a specific method for determining which among the many possible such purposes is most relevant. Our approach is, moreover, conventional in the sense that if judges adopt the set of canons rooted in coalitional politics, then legislators will have the strongest incentive to speak in ways that accurately convey their intentions. Our approach also recognizes that legislation is fundamentally and unalterably ambiguous because, ex ante, legislators simply cannot imagine the variety of settings in which the legislation will apply.

We began this article by highlighting two puzzles in statutory interpretation that are raised by the application of PPT. The first puzzle pertains to the identification of whose policy preferences influence a legislative outcome. Any member of Congress is potentially important to understanding the meaning of a statute. Whose voices should judges and bureaucrats consider important and whose actions should they consider relevant when trying to sort out a law's intent? Indeed, who are the members of the enacting coalition? A necessary condition for a legislator's preferences to be incorporated in the intent of legislation is that the legislator voted in favor of the provision in question. Opponents can reveal intent only indirectly, by offering alternatives that are rejected. Some supporters of a provision will be more critical than others because they control veto gates in the legislative process. Majority coalitions in the two houses of Congress create and maintain rules and structures through which these coalitions maintain themselves and their influence over legislative outcomes. Thus, we can identify individuals whose opinions and actions carry special weight in defining legislation.

The second puzzle concerns how to determine what members of the enacting coalition wanted (and thought they were enacting) in a bill. The structure and process (rules and procedures) of the two houses of Congress not only identify individuals who matter, but also the critical moments in the legislative process at which such individuals are empowered to act in the name of the ruling coalition. Thus, we can identify the points in the process at which the actions and statements of pivotal members are meaningful for interpreting a statute. The economics of signaling inform us about the value of the actions and signals we observe at these critical junctures. Interpretive methods that are based on a better understanding of the costs lawmakers must bear and the penalties they face for lying will produce better inferences about the informativeness of the statements they offer and the choices they make.

74. Henry M. Hart \& Albert M. Sacks, The legal Process: Basic Problems in the MAKING AND APPLICATION OF LAW (1958), cited in WILLIAM N. ESKRIDGE, JR., \& PHILIP P. FRICKEY,

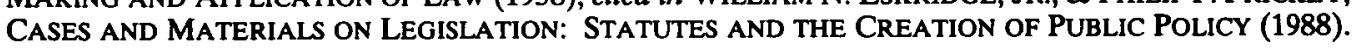

75. Posner, supra note 5 , at 817 . 
